\title{
Paper Stones Revisited: Class Voting, Unionization and the Electoral Decline of the Mainstream Left
}

\author{
Line Rennwald and Jonas Pontusson
}

\begin{abstract}
Relying on post-election surveys, we analyze how class and union membership condition voters' abandonment of mainstream Left parties and the alternatives chosen by former mainstream-Left voters in the period 2001-2015. Inspired by Przeworski and Sprague's Paper Stones (1986), our analysis shows that Left parties face a trade-off between mobilizing workers and other voters and that unionization renders workers more loyal to Left parties that mobilize non-workers. By contrast, unionization does not render non-workers more loyal to Left parties that mobilize workers. Union membership increases the likelihood that workers who abandon the mainstream Left continue to vote. It also increases the likelihood that voters abandon the mainstream Left in favor of radical Left parties rather than Center-Right parties. Finally, we show that workers are more likely to abandon mainstream Left parties in favor of radical Right parties than non-workers and that union membership does not affect their propensity to do so. We conclude that reversing the decline of working-class organization should be a long-term objective of mainstream Left parties.
\end{abstract}

$\mathrm{t}$ is commonplace to construe recent elections in liberal democracies as a struggle between, on the one hand, establishment politicians and parties and, on the other hand, "populist challengers." We focus instead on another conspicuous feature of recent elections: the decline of support for mainstream Left parties, defined as reformist

A list of permanent links to Supplemental Materials provided by the authors precedes the References section.

*Data replication sets are available in Harvard Dataverse at: https://doi.org/10.7910/DVN/YBPZRS

Line Rennwald is a Post-Doctoral Researcher at the University of Geneva, working on class voting, working-class participation in politics and class biases in political representation (line.rennwald@unige.ch). Her doctoral thesis, on working-class support for mainstream Left parties in Austria, France, Germany, Switzerland and the UK, has been published in French. A revised Englishlanguage version is forthcoming.

Jonas Pontusson (D) is Professor of Comparative Politics at the University of Geneva (jonas.pontusson@unige.ch). He has taught at Cornell University and Princeton University and has been a visiting scholar at Nuffield College (Oxford), the Swedish Collegium for Advanced Study in Social Sciences (Uppsala), the Russell Sage Foundation (New York), Sciences Po (Paris), and the Hertie School of Governance (Berlin). He has a long-standing interest in the comparative politics of inequality and redistribution, with an emphasis on labor-market dynamics and the role of trade unions. He is currently directing a five-year research program on citizens' responses to rising income inequality and the implications of income inequality for political representation, funded by the European Research Council (https://unequaldemocracies.unige.ch).

The research for and write-up of this paper have been supported by the European Research Council (Grant Agreement no. 741538). Jonas Pontusson also wishes to acknowledge the support of the National Research Foundation of Korea (NRF-2017S1A3A2066657). Earlier versions of the paper were presented at the Annual Conference of the European Political Science Association (Milan, 2017), the Annual Meeting of the American Political Science Association (San Francisco, 2017), the Norwegian Institute for Social Research (Oslo, 2018), the Swedish Institute for Social Research (Stockholm, 2018), the Institute of Political Science at the University of Bern (2018), the European University Institute (Fiesole, 2018), a workshop at the University of Geneva (2018), and the Wissenschaftszentrum Berlin (2019). For insightful comments and other help, they thank John Ahlquist, Christoph Arndt, Paul Bauer, Michael Becher, Hans-Georg Betz, Björn Bremer, Reto Bürgisser, Henning Finseeras, McCartan Humphries, Konstantin Käppner, Daniel Oesch, Nadja Mosimann, Adam Przeworski, Magnus Rasmussen, and Reto Wüest. 
socialist or social-democratic parties that have historically prioritized the mobilization of working-class voters. As we document later, the vote share of mainstream Left parties has declined in all liberal democracies since the 1990s, often in spectacular fashion. Seeking to shed light on this phenomenon, we present the results of two separate analyses of election surveys. Restricted to survey respondents who voted for the mainstream Left in the previous election, the first analysis addresses the question of who has abandoned the mainstream Left. Restricted to survey respondents who voted for the mainstream Left in the previous election but not in the election that just occurred, the second analysis addresses the question of where former mainstream-Left voters have gone.

Our theoretical framework and empirical analyses are inspired by Paper Stones, the classic 1986 book by Adam Przeworski and John Sprague. Famously, Przeworski and Sprague argue that reformist socialist parties face an electoral dilemma: they need the support of middle-class strata and other non-workers in order to obtain a parliamentary majority, but they tend to loose working-class support when they pursue supra-class strategies. Przeworski and Sprague argue further that unions reinforce the class identity of workers and thereby mitigate the electoral dilemma of socialist parties. Following Przeworki and Sprague, we might reasonably expect that union decline - a pervasive trend across OECD countries over the last twenty to thirty years (see Pontusson 2013)_-renders the trade-off between working-class and middle-class support more severe and that this accounts for some of the electoral difficulties that mainstream Left parties are currently experiencing.

Adopting a broader definition of the working class than Przeworski and Sprague's, we estimate the class profile of new voters for Left parties and explore how this variable affects the propensity of workers and nonworkers - primarily middle-class voters - to abandon the mainstream Left. To anticipate, our analysis suggests that working-class voters are more likely to abandon Left parties that mobilize relatively few working-class voters and that non-workers are more likely to abandon Left parties that primarily mobilize working-class voters. Interacting union membership with the class identity of previous voters and the class profile of new voters, we find that union membership indeed makes workers less likely to abandon Left parties when these parties appeal to non-workers. On the other hand, our results suggest that unionized middle-class voters are particularly prone to abandon Left parties that mobilize working-class voters.

The results of our analysis of the behavior of voters who have abandoned the mainstream Left can be summarized as follows. Controlling for union membership, workers who abandon the mainstream Left are more likely to abstain from voting and to vote for radical Right parties while they are less likely to vote for mainstream Center-Right parties and for Greens than non-workers who abandon the mainstream Left. Among working-class leavers, union membership is associated with a lower probability of abstention and a higher probability of voting for radical Left parties. Among non-workers who abandon the mainstream Left, union membership is associated with a lower probability of voting for mainstream Center-Right parties and, again, with a higher probability of voting for radical Left parties.

Our analyses rely on data from the Comparative Study of Electoral Systems (CSES). As Module 1 of the CSES does not include the retrospective voting question that allows us to identify relevant samples of survey respondents, we rely exclusively on surveys from Modules 2-4. Having dropped a few surveys for lack of data on independent variables of interest, our dataset consists of forty elections in sixteen countries over the period 20012015. ${ }^{1}$

Two limitations of our empirical analysis should be noted at the outset. First, the most recent elections included in the CSES data on which we rely took place in 2015 . Hence our analysis fails to capture the recent rise of radical Right parties as direct competitors to mainstream Left parties. Secondly, our data only allows us to analyze short-term voter trajectories, i.e., changes in voting behavior from one election to the next. It may be that some of the voters who we identify as "leavers" subsequently returned to the mainstream Left or that they subsequently moved to parties other than those that we identify as their "destination." For example, Evans and Mellon's (2016) analysis of British panel data shows that the Conservatives lost more votes to UKIP than Labour did in 2015, but many UKIP voters were former Labour voters who either did not vote or voted for the Conservatives in 2010 .

The rest of the paper is organized as follows. We begin by documenting the decline of mainstream Left parties and then summarize the core arguments in Paper Stones. In the third section, we explain the class categories that we use in our empirical analyses, introduce our measure of the class profile of new Left-party voters, and present descriptive data on the class composition of electorates and unionization by social class as well as the class profile of new Left-party voters. While the fourth section analyzes how class profiles affect the propensity of different voters to abandon the mainstream Left, the fifth section addresses the question of where the leavers have gone. And then we conclude.

\section{The Electoral Decline of the Mainstream Left}

For nineteen liberal democracies, table 1 tracks the electoral decline of mainstream Left parties based on 
official election results. The first column records the postwar election year in which the vote share of the mainstream Left party peaked and the second column records the year of the most recent election. In the following three columns, we adjust for extraordinary elections by reporting the average vote share of the mainstream Left party over two elections: 1) for the peak election and the immediately following election; 2) for the best two elections in the 1990s; and 3) for the two most recent elections. Finally, the last two columns of table 1 report on changes in the average vote share from the 1990 s to the two most recent elections, with change measured first in percentage points and then as a percentage of the 1990 s vote share. ${ }^{2}$

Table 1 sorts countries (parties) into five groups. The first group consists of the three countries in which Social Democrats most successfully mobilized working-class voters in the wake of democratization: Denmark, Norway and Sweden. Aided by the fragmentation of the CenterRight, the mainstream Left held a position of political dominance for several decades in these countries. The second group consists of countries in which Left parties became one of the two main electoral contenders in the post-war period, competing with a united Center-Right party. This characterization applies to the Anglophone Labour parties, operating under more or less majoritarian electoral rules, but also to the Austrian and German Social Democrats. The common characteristic of the third group of countries is that Left parties have always faced strong competition from at least two Center-Right parties. The fourth group consists of Southern European countries in which Socialists parties made dramatic electoral advances in the 1980s, emerging as one of the two main electoral contenders and, in the Greek and Spanish cases, briefly appeared to be on the verge of becoming dominant parties. Finally, Iceland and Italy constitute special cases in that their mainstream Left parties reconstituted themselves in the early 2000s, rendering over-time comparisons of electoral performance less straightforward. ${ }^{3}$

For our purposes, the most striking feature of table 1 is that the average vote share of all mainstream Left parties, regardless of their past performance, has fallen since the 1990s. Averaging across the nineteen countries included in table 1, the vote share of the mainstream Left fell by just about ten percentage points, and by nearly one-third, from the best two elections of 1990s to the two most recent elections. It should come as no surprise that when change is measured in percentage points, small parties have generally done better than large parties. When we instead measure change relative to initial levels, the Greek Socialist Party (PASOK) stands out as the mainstream Left party that has performed the worst by far, having lost more than $80 \%$ of its 1990 s vote share. With vote-share losses between $40 \%$ and 44\%, Iceland's Social Democratic Alliance, the Dutch Labor Party, the Spanish Socialists, and the German SPD have also done very badly at the polls. The French Socialists appear to have done relatively well, but it must be noted that the French figure for recent elections is the average of a very strong performance in $2012(30.4 \%)$ and disastrous performance in 2017 (9.5\%). Ignoring the French case, the British, Irish, and New Zealand Labour parties stand out as the mainstream Left parties whose vote shares have held up the best (falling by $7.7 \%, 12.8 \%$, and $16.0 \%$ respectively).

Aggregating our survey data for the period 2001-2015 provides another way to illustrate the electoral difficulties of mainstream Left parties. Pooling the forty election surveys on which we draw, $32 \%$ of mainstream-Left voters in the previous election either abstained from voting or voted for another party, while $26 \%$ of mainstream-Left voters in the current election were newcomers. By comparison, electoral support for Center-Right parties was considerably more stable, with only $19 \%$ of their voters leaving and newcomers accounting for $21 \%$ of their electorate. ${ }^{4}$ While newcomers outnumbered leavers by two percentage points for Center-Right parties, leavers outnumbered newcomers by six percentage points for mainstream Left parties.

Setting aside the reconstituted Icelandic and Italian parties, all but one of the mainstream Left parties whose vote shares are recorded in table 1 peaked well before the 1990 s and suffered substantial vote-share losses from their peak to the 1990s. The electoral decline of the mainstream Left that occurred over the period covered by our analysis represents the continuation of a trend that dates back to the 1970s (see Rennwald 2015). Arguably, the recent rise of right-wing populist parties with a strong working-class base should be seen as a late manifestation-rather than the cause-of the electoral decline of the mainstream Left.

\section{Paper Stones Revisited}

The analytical history of electoral socialism presented in Paper Stones (1986) proceeds from the "constructivist" or Gramscian - proposition that the rhetoric and activities of political parties determine the voting behavior of individuals. For Przeworski and Sprague, there is nothing natural about politics being organized on the basis of class divisions in society. In their words, "the claims of workers are particularistic, and when workers organize as a class they seek to impose upon the entire society the image of classes, each endowed with particularistic interests." By contrast, capitalists represent themselves as a class "only in moments of folly." Their response to the particularistic claims of the working class "is not a particularism of the bourgeoisie but ideologies which deny altogether the salience of class interests, either by posing a universalistic model of society composed of individual-citizens whose interests are in harmony or by evoking alternative particularisms of religion, language, ethnicity, etc." In short, the salience of class for politics and, in particular, for the political behavior of workers depends on the presence of 
Table 1

The vote share of mainstream Left parties

\begin{tabular}{|c|c|c|c|c|c|c|c|}
\hline & \multicolumn{2}{|c|}{ Election Years } & \multicolumn{3}{|c|}{ Average Vote Share } & \multicolumn{2}{|c|}{ Change since 1990s } \\
\hline & $\begin{array}{l}\text { Post- } \\
1960 \\
\text { Peak }\end{array}$ & $\begin{array}{c}\text { Most } \\
\text { Recent }\end{array}$ & $\begin{array}{l}\text { Peak and } \\
\text { Next } \\
\text { Election }\end{array}$ & $\begin{array}{c}\text { Best Two Elections } \\
\text { between } 1990 \text { and } \\
1999\end{array}$ & $\begin{array}{l}\text { Two Most } \\
\text { Recent } \\
\text { Elections }\end{array}$ & $\begin{array}{l}\text { Percentage } \\
\text { Points }\end{array}$ & Percentage \\
\hline \multicolumn{8}{|l|}{$\begin{array}{l}\text { 1. Long-Term } \\
\text { dominant } \\
\text { parties: }\end{array}$} \\
\hline Norway & 1961 & 2017 & 45.0 & 36.0 & 29.1 & -6.9 & -19.4 \\
\hline Denmark & 1960 & 2019 & 42.0 & 36.7 & 26.1 & -10.6 & -28.9 \\
\hline Sweden & 1968 & 2018 & 47.7 & 41.5 & 29.7 & -11.8 & -28.4 \\
\hline \multicolumn{8}{|l|}{$\begin{array}{l}\text { 2. Long-term } \\
\text { contenders: }\end{array}$} \\
\hline UK & 1966 & 2019 & 45.6 & 39.1 & 36.1 & -3.0 & -7.7 \\
\hline Australia & 1972 & 2016 & 49.2 & 42.2 & 34.1 & -8.1 & -19.2 \\
\hline Germany & 1972 & 2017 & 44.2 & 38.7 & 23.1 & -15.6 & -40.3 \\
\hline New Zealand & 1972 & 2017 & 44.0 & 36.9 & 31.0 & -5.9 & -16.0 \\
\hline Austria & 1979 & 2017 & 49.3 & 40.5 & 27.7 & -12.8 & -31.6 \\
\hline \multicolumn{8}{|l|}{$\begin{array}{l}\text { 3. Permanent } \\
\text { also-rans: }\end{array}$} \\
\hline Belgium & 1961 & 2019 & 32.5 & 25.0 & 18.3 & -6.7 & -26.8 \\
\hline Switzerland & 1963 & 2019 & 25.1 & 22.2 & 17.8 & -4.4 & -19.8 \\
\hline Ireland & 1969 & 2016 & 15.4 & 14.9 & 13.0 & -1.9 & -12.8 \\
\hline Netherlands & 1977 & 2017 & 31.1 & 26.5 & 15.3 & -11.2 & -42.3 \\
\hline Finland & 1995 & 2019 & 25.6 & 25.6 & 17.1 & -8.5 & -33.2 \\
\hline \multicolumn{8}{|l|}{$\begin{array}{l}\text { 4. Post-1980 } \\
\text { risers: }\end{array}$} \\
\hline France & 1981 & 2017 & 34.0 & 22.3 & 20.0 & -2.3 & -10.3 \\
\hline Greece & 1981 & 2019 & 47.0 & 44.2 & 7.2 & -37.0 & -83.7 \\
\hline Spain & 1982 & 2019 & 46.4 & 38.2 & 22.3 & -15.9 & -41.6 \\
\hline Portugal & 2005 & 2019 & 42.1 & 43.9 & 34.4 & -9.5 & -21.6 \\
\hline \multicolumn{8}{|l|}{$\begin{array}{l}\text { 5. Recon- } \\
\text { stituted } \\
\text { parties }\end{array}$} \\
\hline Iceland & 2003 & 2018 & 28.9 & - & 16.4 & $-12.5^{\star}$ & $-43.3^{*}$ \\
\hline Italy & 2008 & 2018 & 29.3 & - & 22.1 & $-7.2^{\star}$ & $-24.6^{\star}$ \\
\hline Average & & & & & & -10.1 & -29.0 \\
\hline
\end{tabular}

political parties that seek to mobilize workers as a class (Przeworski and Sprague 1986, 8-10).

Przeworski and Sprague proceed to document that, contrary to the expectations of Marx and other nineteenth-century socialist thinkers, the development of industrial capitalism did not usher in wholesale proletarianization. Farmers, shopkeepers, and other small businessmen were indeed displaced, but they were replaced by new middle classes as well as manual workers. According to Przeworski and Sprague's census-based estimates for seven West European countries, manual workers as a proportion of the electorate peaked some time between 1900 and 1950. Workers constituted just about $50 \%$ of the Belgian electorate in the early 1920 s, but their share of the electorate never exceeded $40 \%$ in the other six countries (Przeworski and Sprague 1986, 39).
Recognizing that the mobilization of working-class voters could not possibly deliver the electoral majority required to implement systemic reforms by democratic means, socialist parties began to court other electoral constituencies - in the first instance, small farmers and farm laborers, but also, increasingly, the new middle classes. In pursuing what Przeworski and Sprague refer to as "supra-class strategies," they abandoned or, at least, postponed some of their more radical ambitions. This is a familiar story and its retelling by Przeworski and Sprague is not terribly distinctive. What makes Paper Stones an important book is the observation that reformist socialist parties, firmly committed to democratic principles and pursuing supra-class strategies, have very rarely succeeded in mobilizing a majority of voters. The rapid rise of these parties in the wake of democratization was followed, from 
the 1940s onwards, by a long period of electoral stagnation. Przeworski and Sprague's explanation of this puzzle boils down to the following proposition: seeking to mobilize support among non-workers by making supraclass appeals, socialist parties undermine the salience of class to workers and thereby enable other political parties to compete for the working-class vote.

Analyzing aggregate voting patterns from 1900 to 1980, Przeworski and Sprague identify a persistent trade-off: as socialist parties have gained support among other classes, they have invariably lost support among workers. Their analysis also shows that the steepness of this trade-off varies considerably across countries and, as a result, so does the "carrying capacity" of socialist parties. Over the time period covered by Przeworksi and Sprague's analysis, the trade-offs faced by Danish, Norwegian, and Swedish Social Democrats were less steep than the tradeoffs faced by their Belgian, Finnish, French, and German counterparts. In other words, the Scandinavian parties suffered smaller losses among working-class voters as they expanded their electoral base beyond the working class.

Seeking to explain cross-national variation in the steepness of the electoral trade-off, Przeworski and Sprague argue that the presence of rival parties mobilizing workers on the basis of class (communist parties) or some other "particularistic identity" (religion, language, ethnicity) render socialist parties that pursue supra-class strategies particularly vulnerable to working-class defections (Przeworski and Sprague 1986, 71-74). However, their main explanation of variation in the steepness of the tradeoff has to do with unionization. Unions, Przeworski and Sprague argue (74-79), serve to sustain the class identity of workers and thereby reduce the need for socialist parties to emphasize class politics in order to retain the support of workers. ${ }^{5}$

As noted by Sainsbury (1990), Przeworski and Sprague's empirical analysis proceeds from a narrow and arguably old-fashioned conceptualization of the working class as consisting exclusively of manual workers employed in mining, manufacturing, construction, transport and agriculture. Sainsbury $(1990,34)$ also points out that Przeworski and Sprague's analysis does not involve any direct observations of the proportion of workers voting socialist. Instead, Przeworski and Sprague estimate this critical parameter based on the proportion of workers within the population eligible to vote and official election results.

Our individual-level analysis of survey data is meant to complement Przeworski and Sprague's macro-level historical analysis of election results, but also to address the concerns raised by Sainsbury. Analyzing survey data allows us to observe directly the class profile of Left party electorates and to assess whether or not working-class voters become less loyal supporters of Left parties as these parties mobilize other voters. As we explain later, we pursue this strategy based on a definition of the working class that is considerably broader than Przeworski and Sprague's definition. We also seek to break new ground by exploring the effects of union membership among middleclass voters, departing from Przeworski and Sprague's conceptualization of unionization as exclusively a working-class phenomenon.

In principle, the trade-off argument pertains to voters switching to Left parties as well as voters abandoning Left parties. For the time period covered by our analysis, it makes sense to focus on voters leaving the mainstream Left. The core hypothesis that we derive from Paper Stones is that workers are less likely to abandon the mainstream Left parties than other voters when these parties actively appeal to working-class voters and, conversely, that they are more likely to abandon the mainstream Left parties when they do not target their electoral appeals in this fashion. Also derived from Przeworski and Sprague's argumentation, our second hypothesis is that unionized workers are less responsive to the mobilizational strategies of Left parties than workers who are not union members, i.e., that they are less likely to abandon mainstream Left parties that mobilize middle-class voters. As for the effects of unionization among middle-class voters, we do not have strong prior expectations, but it seems reasonable to suppose that unionization renders middle-class voters as well as working-class voters more likely to vote for Left parties and, by extension, more loyal to these parties.

Leaving individual-level implications aside for the time being, Przeworski and Sprague's argumentation suggests that unionization affects the carrying capacity or, in other words, the long-term vote share of Left parties. Plotting changes in the average vote share of Left parties from the 1990 s to the two most recent elections against changes in union density from 1990 to 2016 (as recorded by Visser 2019), there does not appear to be any association whatsoever between these two developments. As reported in table 2, however, the picture changes if we estimate a simple OLS regression model with a couple of dummy variables as controls. The first dummy variable takes the value of 1 for countries with a small effective number of parties, averaged over the period 1990-2017 (Australia, Ireland, New Zealand, Portugal, Spain and the UK). The second dummy variable takes the value of 1 for countries that experienced a sharp economic downturn while the mainstream Left party held the office of prime minister in 2008-2011 (Iceland, Greece, Portugal, Spain, and the UK). When both of these variables are included in the model, the presence of more competitors and incumbency during crisis are both associated with a larger decline in the vote share of mainstream Left parties and, most importantly for our purposes, a one-percentage-point decline in union density is associated with a vote-share decline of nearly half a percentage point. Given the small number of 


\begin{tabular}{|c|c|c|c|c|}
\hline & (1) & (2) & (3) & (4) \\
\hline$\Delta$ union density & $\begin{array}{l}-.042 \\
(.826)\end{array}$ & $\begin{array}{c}.075 \\
(.736)\end{array}$ & $\begin{array}{c}.037 \\
(.840)\end{array}$ & $\begin{array}{l}.459^{\star} \\
(.020)\end{array}$ \\
\hline Two-party dominance & - & $\begin{array}{l}4.765 \\
(.309)\end{array}$ & - & $\begin{array}{c}14.123^{\star *} \\
(.002)\end{array}$ \\
\hline Crisis + incumbency & - & - & $\begin{array}{c}-7.647^{+} \\
(.069)\end{array}$ & $\begin{array}{c}-15.201^{\star *} \\
(.001)\end{array}$ \\
\hline Constant & $\begin{array}{c}-10.599 \\
(.002)\end{array}$ & $\begin{array}{c}-10.715 \\
(.002)\end{array}$ & $\begin{array}{r}-7.651 \\
(.024)\end{array}$ & $\begin{array}{r}-5.370 \\
(.040)\end{array}$ \\
\hline $\mathrm{N}$ & 19 & 19 & 19 & 19 \\
\hline Adjusted R-square & -.056 & -.049 & .093 & .488 \\
\hline \multicolumn{5}{|c|}{ Notes: P-values in parentheses: ${ }^{+} p<0.10,{ }^{*} p<0.05,{ }^{* \star} p<0.01$} \\
\hline \multicolumn{5}{|c|}{$\begin{array}{l}\text { The dependent variable is the difference in the average vote share from elections in the } 1990 \text { s to the two most recent elections, as } \\
\text { reported in table } 1 \text {. Change in union density is the difference between } 1990 \text { and } 2016 \text { figures, as recorded by Visser } 2019 \text {. The dummy } \\
\text { for two-party dominance takes the value of } 1 \text { if the average effective number of parties over the period } 1990-2017 \text { is } 3 \text { or less, based on } \\
\text { Gallagher n.d. With a score of } 3.006 \text {, Spain is coded as a case of two-party dominance. The country with the next lowest effective } \\
\text { number of parties is Austria, at 3.59. Refer to the text for further explanations. }\end{array}$} \\
\hline
\end{tabular}

observations, these results should surely be taken with a grain of salt, but they suggest that union decline might indeed be an important factor behind the electoral decline of mainstream Left parties. ${ }^{6}$

\section{Class Membership of Voters and Class Profiles of Parties}

Social class is the critical individual-level variable in our analysis of where mainstream-Left voters have gone as well as in our analysis of who has abandoned the mainstream Left. In identifying election-survey respondents as members of social classes, we rely on the occupational class schema proposed by Oesch (2006). The Oesch schema distinguishes classes-or class segments-based on work logics as well as skills and the nature of employment contracts. The vertical dimension - labor market status_-serves to distinguish between employers and self-employed, on the one hand, and employees, on the other hand, and then to distinguish two broad classes of employees: the middle class and the working class. The horizontal dimension in turn serves to identify three distinct segments of the middle class and the working class. In Oesch's terminology, the middle class consists of managers, technical experts, and socio-cultural professionals while the working class consists of clerical staff, production workers, and service workers. Again on the vertical dimension, Oesch distinguishes further between more- and less-skilled members of these six "classes."

As documented by Oesch and many others, low-skilled individuals employed in services occupy disadvantageous positions in the labor market that are comparable to (or worse than) the positions of production workers in terms of job security, occupational status, and earnings. While these individuals are less likely to be unionized and may be less likely to self-identify as "working class" than production workers, they are surely part of the working class as defined by objective criteria. In our view, "clerical staff" constitutes a more heterogeneous occupational category and assigning all individuals in this category to "the working class" stretches the latter concept too far. For the purposes of our paper, we define "the working class" as production and service workers and categorize clerical staff, along with middle-class professionals, managers, farmers, and businessmen as "non-workers."

Thus conceived, "non-workers" constitute a broad swath of the electorate and it seems plausible to suppose that some non-workers will be more attracted to parties with a strong working-class profile than others. In particular, an extensive literature, spearheaded by Kitschelt (1994) and Kriesi (1998), emphasizes the importance of socio-cultural professionals as an electoral constituency that has become increasingly important to Left parties since the 1970s (see also Kitschelt and Rehm 2014; Häusermann and Kriesi 2015; Gingrich and Häusermann 2015). The core claim of this literature is that sociocultural work ("people processing”) makes people more disposed in favor of progressive positions on the distributive dimension as well as the cultural dimension of politics and that socio-cultural professionals constitute a natural ally of workers in the domain of redistributive politics. As recognized by several contributions to the literature, the fact that socio-cultural professionals commonly work in the public sector arguably provides 
another, more "self-interested" basis for the apparent alignment of socio-cultural professionals with the working class as core constituencies of mainstream Left parties over the last two or three decades.

In keeping with the worker-centric framework of Paper Stones, we begin by estimating the trade-off between mobilizing workers and non-workers and then explore whether or not socio-cultural professionals respond differently to working-class mobilization than other non-workers. The category "non-workers" could, of course, be disaggregated further-as, indeed, could the category "workers"-but we do not have any strong theoretical reasons for doing so and it is not our goal, in this paper, to contribute to the empirical literature on occupation and vote choice.

We present CSES-based estimates of the distribution of the total electorate sorted into workers, socio-cultural professionals and other non-workers as well as estimates of unionization by social class in online appendices 2 and 3. By our definition, the working class constitutes, on average, $33 \%$ of the electorate in the sixteen countries included in our analysis. Australia and Switzerland stand out as the countries with the smallest working classes $(22 \%-23 \%)$. In the other fourteen countries, the working-class share of the electorate ranges between 27\% (Greece) and 43\% (Finland). The working class is nowhere close to an electoral majority, but it represents a large electoral constituency, which Left parties ignore at their peril. On average, socio-cultural professionals constitute $17 \%$ of the electorate in our sixteen countries. Setting aside the exceptional case of Spain $(7 \%)$, their share of the electorate ranges between $14 \%$ and $25 \%$. Averaging across the sixteen countries, voters who are neither workers nor socio-cultural professionals constitute $50 \%$ the electorate, but workers and socio-cultural professionals together constitute an electoral majority in ten of these countries. ${ }^{7}$

As shown in online appendix 3, the rate of unionization of socio-cultural professionals is equivalent to or higher than the rate of unionization among production and service workers in all but one country (Norway). Averaging across the sixteen countries, the rate of unionization for socio-cultural professionals exceeds the rate of unionization for production and service workers by five percentage points ( $46 \%$ compared to $41 \%$ ). The average unionization rate of "other non-workers" is significantly lower (32\%), but there are a handful of countries in which unionization of "other non-workers" is more or less equivalent with unionization of workers (France, Spain, Switzerland and the UK).

In the first set of analyses that we present here, we explore electoral trade-offs by analysing how the mobilization strategies of mainstream Left parties, measured by the class profile of new voters that they attract, condition the probability that members of different classes will abandon these parties. Our measure of the class profile of electoral mobilization is the percentage of workers (as defined earlier) among new voters for the mainstream Left divided by the (election-specific) percentage of workers in the potential population of new voters, i.e., the percentage of workers in the subset of the electorate that did not vote for the mainstream Left in the previous election. This ratio takes a value greater than 1 if workers are overrepresented among new voters, relative to their share of potential new voters, and a value of less than 1 if workers are underrepresented among new voters. New voters may be either first-time voters or voters who switched to the party in the election that just occurred. $^{8}$

Table 3 provides descriptive data on the class profile of electoral mobilization, which ranges from .79 for the Swiss Social Democrats in the election of 2011 to 2.21 for the Greek Socialists in the election of 2012. The Greek figure is problematic because 2012 was a catastrophic election for the Greek socialists and only two new socialist voters were recorded by the election survey. The Austrian election of 2013 is as another case with very few new voters for the mainstream Left included in the survey. For the remaining thirty-eight elections, the figures presented in table 3 are based on calculations with at least thirty new voters for the mainstream Left and the maximum score is 1.76 (Finland in 2011). Among the parties for which we have at least two observations of electoral performance, Australian Labour, New Zealand Labour, and the Swedish Social Democrats stand out as having most consistently mobilized more workers than non-workers over the period 2001-2015.

Following Przeworski and Sprague (1986) as well as recent literature that emphasizes "supply-side" explanations of class voting (e.g., Evans and De Graaf 2013; Rennwald and Evans 2014; Rennwald 2015), we assume that the class composition of new voters reflects, at least in part, the mobilization strategies that Left parties pursue and that old as well as new voters for the mainstream Left respond to the appeals that these parties make during electoral campaigns. Parties seeking to appeal to working-class voters are likely to emphasize different issues and to position themselves differently on some issues than parties seeking to appeal to middle-class voters. It is tempting to assume that Left parties that seek mobilize workers will be more "leftist" in their programmatic orientation, at least with respect to policies with important distributive implications, but it is important to keep in mind, we think, that Labour and Social Democratic parties that successfully mobilized workingclass majorities in the post-war era often did so on the basis of quite moderate political platforms. Arguably, moderate and leftist policy proposals alike might be framed in more or less "workerist" terms and the framing of policies is as important as the policies themselves (cf. 
Table 3

Class profile of electoral mobilization by mainstream Left parties, 2001-2015

\begin{tabular}{|c|c|c|c|c|c|}
\hline & 2001-04 & 2005-08 & 2009-11 & 2012-15 & average \\
\hline Australia 2004, 2007, 2013 & $0.99(124)$ & $1.33(257)$ & - & $1.59(148)$ & 1.39 \\
\hline Austria 2013 & - & - & - & $1.47(12)$ & 1.47 \\
\hline Denmark 2001 & $1.07(54)$ & - & - & - & 1.07 \\
\hline Finland 2003, 2007, 2011, 2015 & $0.95(40)$ & $1.05(31)$ & $1.76(30)$ & $1.07(30)$ & 1.21 \\
\hline France 2012 & - & - & - & $1.04(200)$ & 1.04 \\
\hline Germany 2002, 2005, 2009, 2013 & $1.19(131)$ & $0.91(142)$ & $0.87(33)$ & $0.89(53)$ & 0.96 \\
\hline Greece 2009, 2012 & - & - & $0.81(41)$ & $2.21(2)$ & 1.51 \\
\hline Iceland 2003, 2007, 2009, 2013 & $1.08(138)$ & $0.88(81)$ & $1.06(95)$ & $1.19(31)$ & 1.05 \\
\hline Ireland 2002, 2007 & $0.95(53)$ & $0.88(43)$ & - & - & 0.93 \\
\hline Netherlands 2002, 2006, 2010 & $0.88(34)$ & $1.06(74)$ & $0.96(95)$ & - & 0.97 \\
\hline New Zealand 2002, 2008, 2011, 2014 & $1.24(130)$ & $1.75(51)$ & $1.67(65)$ & $1.60(81)$ & 1.54 \\
\hline Norway 2001, 2005, 2009, 2013 & $0.98(39)$ & $1.04(155)$ & $1.08(112)$ & $1.06(60)$ & 1.04 \\
\hline Spain 2004 & $1.31(98)$ & - & - & - & 1.31 \\
\hline Sweden 2002, 2006, 2014 & $1.34(79)$ & $1.51(64)$ & - & $1.50(65)$ & 1.45 \\
\hline Switzerland 2011 & - & - & $0.79(169)$ & - & 0.79 \\
\hline United Kingdom 2005, 2015 & - & $1.07(35)$ & - & $0.82(102)$ & 0.91 \\
\hline
\end{tabular}

The number of survey respondents who switched to the mainstream Left in a given election is provided in parentheses. Calculations based on CSES data. Refer to the text for our operationalization of "class profile."

Evans and Tilley 2017; Thau 2017). We shall return to this question in the concluding discussion.

\section{Voter Responses to the Class Profile of Electoral Mobilization}

As noted at the outset, we rely on harmonized national post-election surveys assembled by the Comparative Study of Electoral Systems (CSES) to analyze determinants of individual decisions to abandon the mainstream Left and then to explore, in a second step (the fifth section), where the leavers have gone. Both sets of analyses are restricted to survey respondents who, by their own account, voted for the mainstream Left in the election prior to the one that just occurred. With nested data and dichotomous dependent variables, we follow the standard practice of estimating hierarchical logistic regression models, with country-elections as the level-2 units. However, this setup does not fully take into account the complex structure of our data. For eleven out of sixteen countries, we have observations for at least two elections. Following Schmidt-Catran and Fairbrother (2016), we take this complication into account by estimating random effects at the country level as well as the country-election level. Thus our analysis controls not only for unique characteristics of particular elections, but also for enduring features of electoral competition that are specific to a particular country. ${ }^{\text {? }}$

In our first set of analyses, the dependent variable takes the value 1 for respondents who abstained or voted for another party in the election that just took place and zero for those who again voted for the mainstream Left party. The independent variables of theoretical interest at the individual level are social class and union membership, both captured by dummy variables. As explained earlier, our core hypotheses concern the interaction of class and union membership with the class profile of electoral mobilization by mainstream Left parties and we use the relative representation of workers among new voters as a proxy for parties' mobilization efforts.

Our regression models include individual-level controls for age, gender, education and residence (village, small or medium city, suburbs, large city). These are standard socio-demographic control variables that have been shown to be relevant predictors for mainstream Left voting, but we do not have strong theoretical expectations as to how they might affect probabilities of abandoning the mainstream Left or the trajectories of voters who abandon the mainstream Left.

To take account of options available to voters who consider abandoning the mainstream Left party, we include the vote shares of Radical Left, Radical Right, and Green parties in the previous election as macro-level variables. In addition, we include a dummy variable that takes the value of 1 if the mainstream Left party was in government going into the election and another dummy variable that takes the value of 1 for elections during or immediately following the crisis of 2008-2010 if the mainstream Left party held the office of prime minister at the time and the crisis was very severe. ${ }^{10}$

To begin with, we distinguish between workers and non-workers and interact the dummy for working-class respondent with the class profile of new voters, treating union membership as a control variable. For the forty election-years in our dataset, figure 1a presents our estimates of the average marginal effect of the respondent 
Figure 1

(a) The average marginal effect of social class conditional on the class profile of electoral mobilization and $95 \%$ confidence intervals (forty elections), (b) Predicted probabilities of leaving the mainstream Left by social class conditional on the class profile of electoral mobilization (forty elections).

A

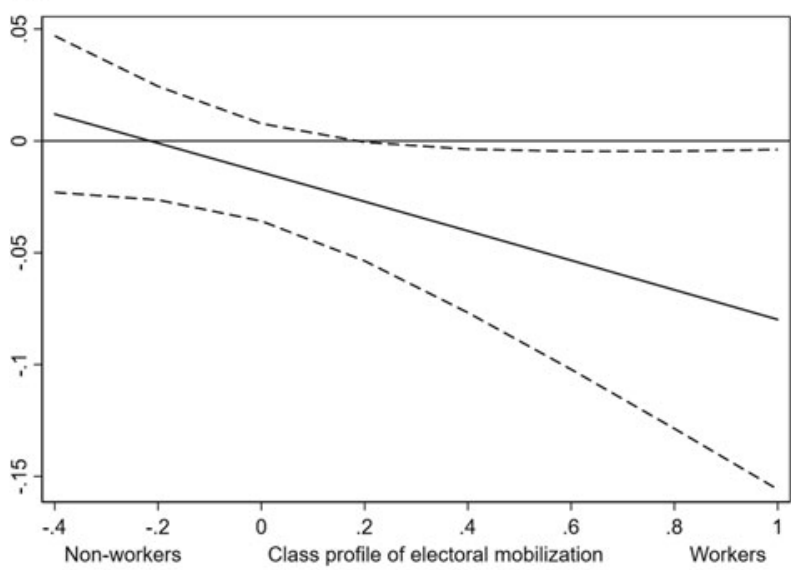

B

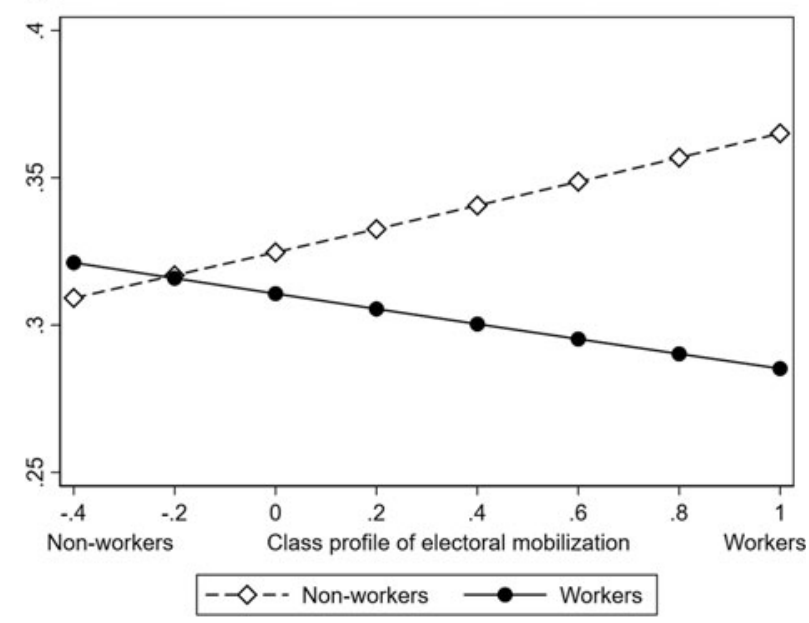

Based on Model 3 in online appendix 5.

being a worker on the probability of abandoning the mainstream Left conditional on the class profile of new voters for the mainstream Left while figure $1 b$ shows estimated probabilities of workers and non-workers abandoning the mainstream Left conditional on the class profile of new voters. ${ }^{11}$ Figures $2 \mathrm{a}$ and $2 \mathrm{~b}$ in turn show the results that we obtain when we restrict the analysis to the thirty-eight elections for which we have at least thirty new voters for the mainstream Left (i.e., drop the Greek election of 2012 and the Austrian election of 2013). Wary of the small-N problem, we consider the latter set of results to be more meaningful, but it is instructive to consider both sets of results. ${ }^{2}$

\section{Figure 2}

(a) The average marginal effect of social class conditional on the class profile of electoral mobilization and $95 \%$ confidence intervals, without Greece 2012 and Austria 2013 (thirtyeight elections), (b) Predicted probabilities of leaving the mainstream Left by social class conditional on the class profile of electoral mobilization (thirty-eight elections)

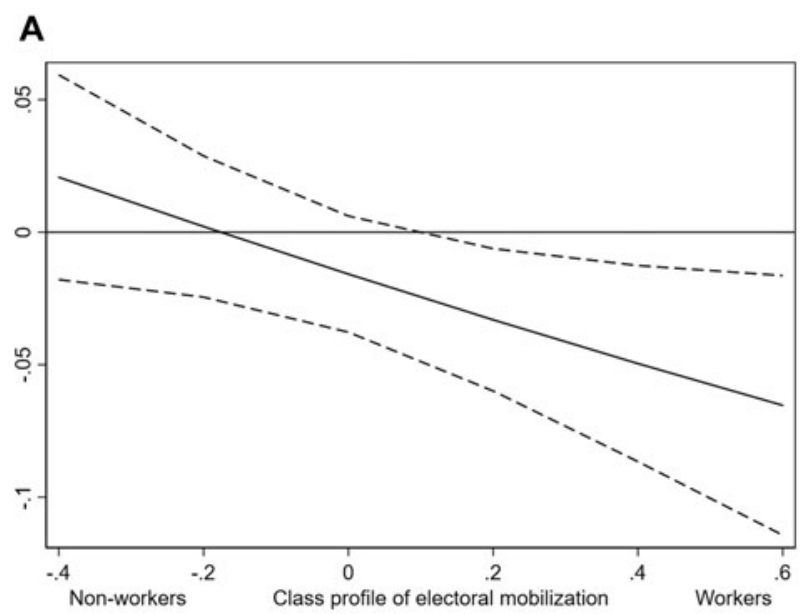

B

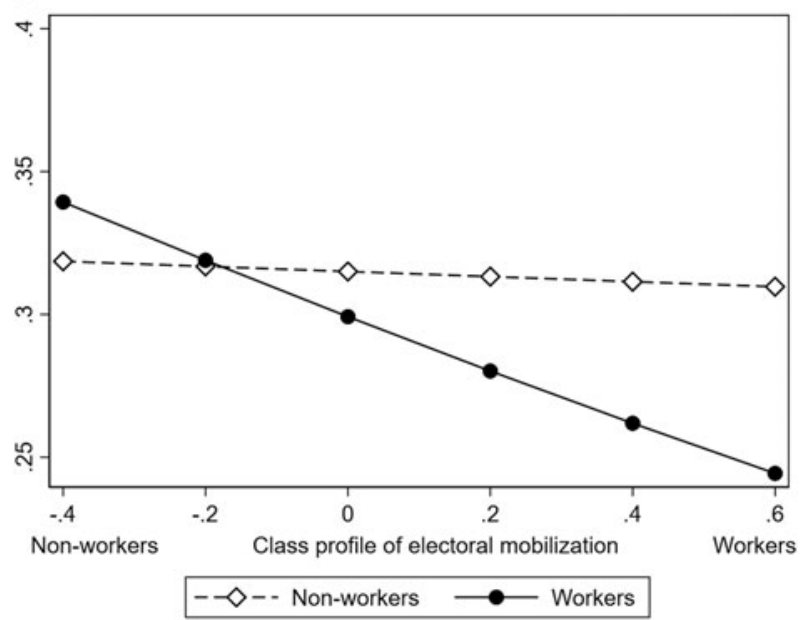

Based on Model 3 in online appendix 6.

With or without the Greece 2012 and Austria 2013 elections, we find that middle-class supporters are more likely to abandon mainstream Left parties than workingclass supporters when these parties primarily mobilize new working-class voters. At the maximum level of overrepresentation of workers among new voters, the difference in the probabilities of middle-class and working-class supporters abandoning the mainstream Left is slightly greater than eight percentage points. On the other hand, there appears to be no difference in the propensity of middle-class and working-class supporters to abandon 
mainstream Left parties that primarily mobilize new middle-class voters. When the cases with less than thirty new voters are included, the trade-off between workingclass support and middle-class support stems as much, if not more, from middle-class aversion to Left parties that mobilize workers than from working-class aversion to Left parties that mobilize non-workers, but when we drop those two cases working-class voters seem to be more responsive to the class profile of newcomers.

The differences in the probability of workers or nonworkers abandoning the mainstream Left across the range of values for the class profile of new voters do not clear conventional thresholds of statistical significance, but, as figures $1 \mathrm{a}$ and $2 \mathrm{a}$ illustrate, the differences between workers and non-workers are significant with $95 \%$ confidence for values greater than 0.1 . In other words, the differential responsiveness of workers and non-workers to the class profile of new voters is statistically significant when these groups are considered jointly.

The flat line for non-workers in figure $2 b$ could be because non-workers include socio-cultural professionals, commonly conceived as a core constituency of the mainstream Left and a natural ally of Left-leaning workers. Exploring this question, figure 3 replicates figure $2 \mathrm{~b}$ based on estimating a model that treats socio-cultural professionals as separate from other non-workers. In a nutshell, we find no evidence that "other non-workers" are more responsive to the class profile of party appeals than sociocultural professionals. ${ }^{13}$

Figure 3

Predicted probabilities of leaving the mainstream Left by class (sociocultural professionals as separate category), conditional on the class profile of electoral mobilization (thirtyeight elections)

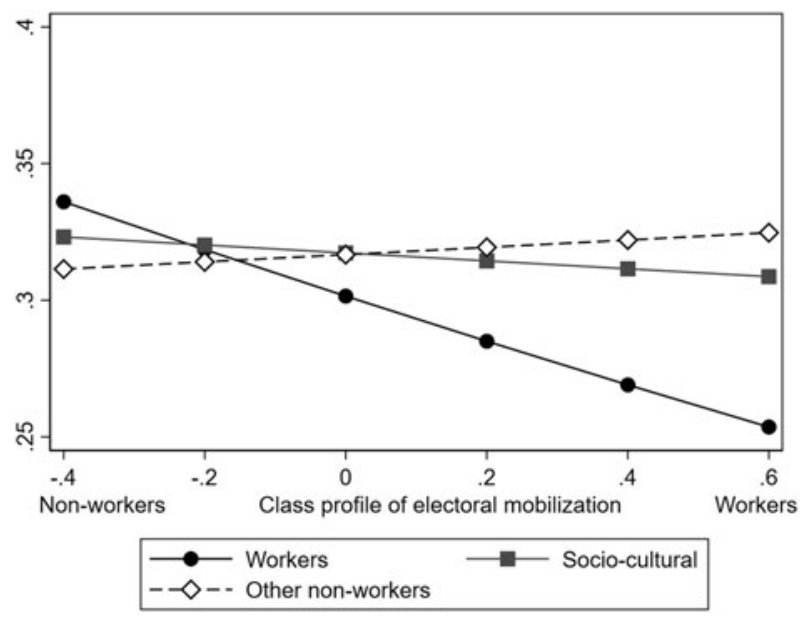

Based on Model 1 in online appendix 7.
Figure $2 \mathrm{~B}$ and figure 3 both suggest that mobilizing workers is a win-win strategy for mainstream Left parties, as it does not appear to be associated with defections by middle-class supporters of these parties. However, there are more potential middle-class voters than working-class voters and thus it may well be the case that appealing to middleclass voters is still the most rational vote-maximizing strategy for these parties.

Turning to the role of unionization, the first thing to note is that all of our models yield a direct effect of union membership that is negative and highly significant. Everything else being equal, union members are less likely to abandon the mainstream Left than nonmembers. Sticking with the three-class setup (i.e., treating socio-cultural professional as separate from other nonworkers), and with data for thirty-eight elections, we explore the role of unionization further by estimating a model with three-way interactions between respondents' class, union membership, and representation of workers among new mainstream Left voters. Table 4 summarizes the results of this exercise (refer to online appendix 7 for full regression results). Consistent with Przeworski and Sprague's hypothesis, we find that unionization of production and service workers indeed mitigates the trade-off faced by mainstream Left parties: unionized workers are less likely to abandon mainstream Left parties when they appeal to non-workers (from negative values to the mean values of class profile) than workers who are not union members. When Left parties primarily mobilize workers (positive values), the union effect among workers disappears, i.e., there is no significant difference in the probability of union members and non-members to abandon the mainstream Left. By contrast, middle-class unionization seems to reinforce the trade-off faced by Left parties. Relative to non-members, socio-cultural professionals as well as other non-workers who are union members are less likely to abandon mainstream Left parties that primarily appeal to non-workers, but they are not less likely to abandon mainstream Left parties that primarily appeal to workers. As we shall see in the next section, unionized non-workers and especially unionized sociocultural professionals have a particular affinity for Greens and radical Left parties. Arguably, this is the main reason for the apparently counter-intuitive effect of union membership on loyalty to mainstream Left parties that seek to mobilize workers.

Based on a three-way interaction model that simply distinguishes between workers and non-workers (i.e., ignores the distinction between socio-cultural professionals and other non-workers), figure 4 a replicates figure $2 \mathrm{~b}$ for non-unionized respondents while figure $4 \mathrm{~b}$ replicates it for unionized respondents. With the difference in class-specific probabilities of abandoning the mainstream Left approaching ten percentage points when over-representation of workers among new voters takes 
Figure 4

Predicted probabilities of leaving the mainstream Left by social class conditional on the class profile of electoral mobilization (thirtyeight elections)
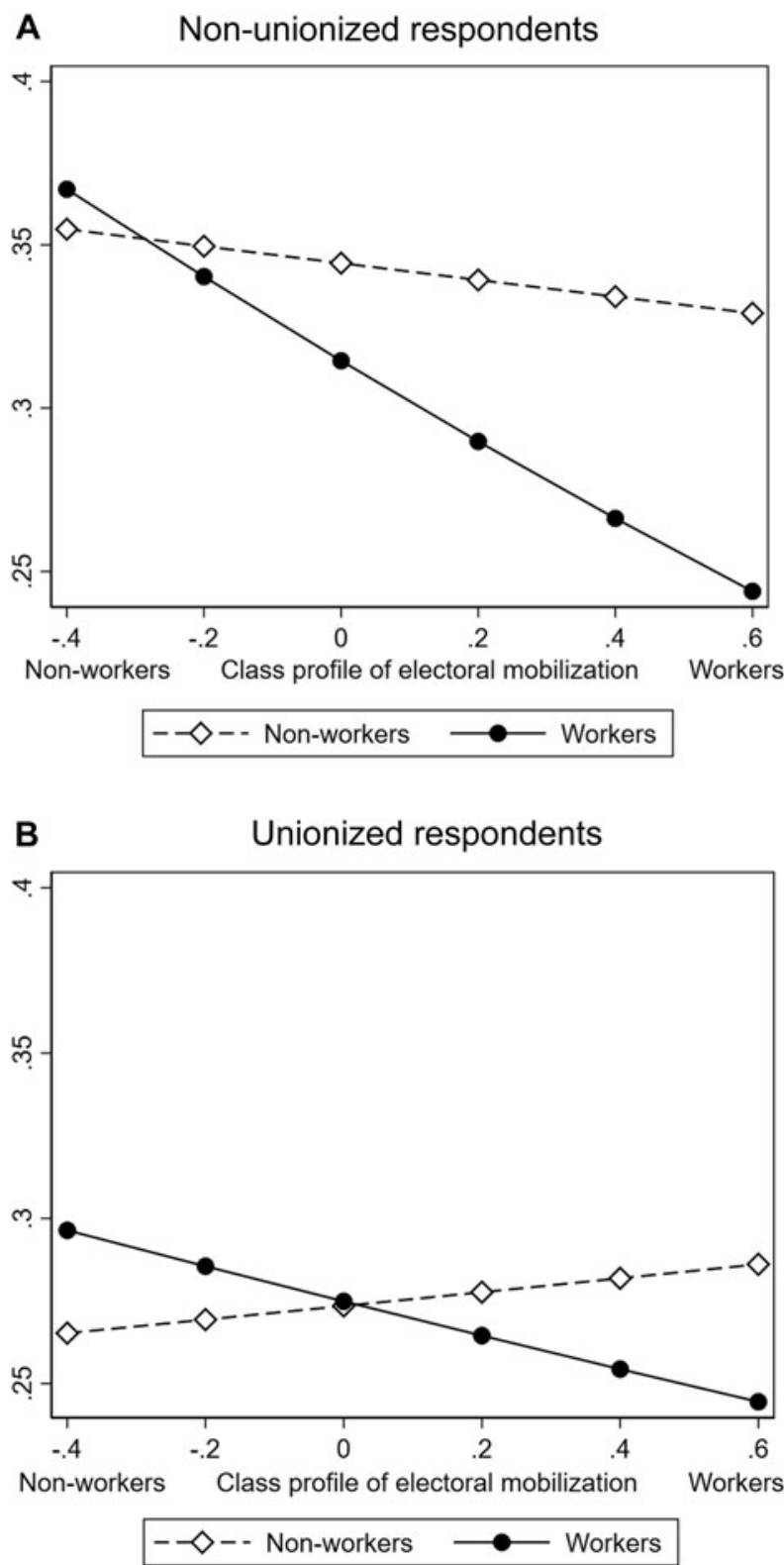

Based on Model 4 in online appendix 6.

its maximum value, the trade-off between working-class and middle-class support is more pronounced than in figure $2 \mathrm{~b}$ when we only look at non-unionized respondents. Comparing the two panels in figure 4, it is immediately apparent not only that unionized respondents are less likely to abandon mainstream Left parties, regardless of the class profile of new voters, but also that the trade-off between working-class and middle-class support is much less steep among unionized respondents than among non-unionized respondents. As shown in figure $5 b$, the trade-off for unionized respondents does not clear the $95 \%$ threshold for statistical significance. The difference in the steepness of the trade-offs appears to be primarily due to the stronger loyalty of unionized working-class voters to Left parties that mobilize non-workers. In sum, our results indicate that working-class de-unionization does indeed reinforce the electoral dilemma identified by Przeworski

\section{Figure 5}

The average marginal effect of social class conditional on the class profile of electoral mobilization, with $95 \%$ confidence intervals (thirty-eight elections)
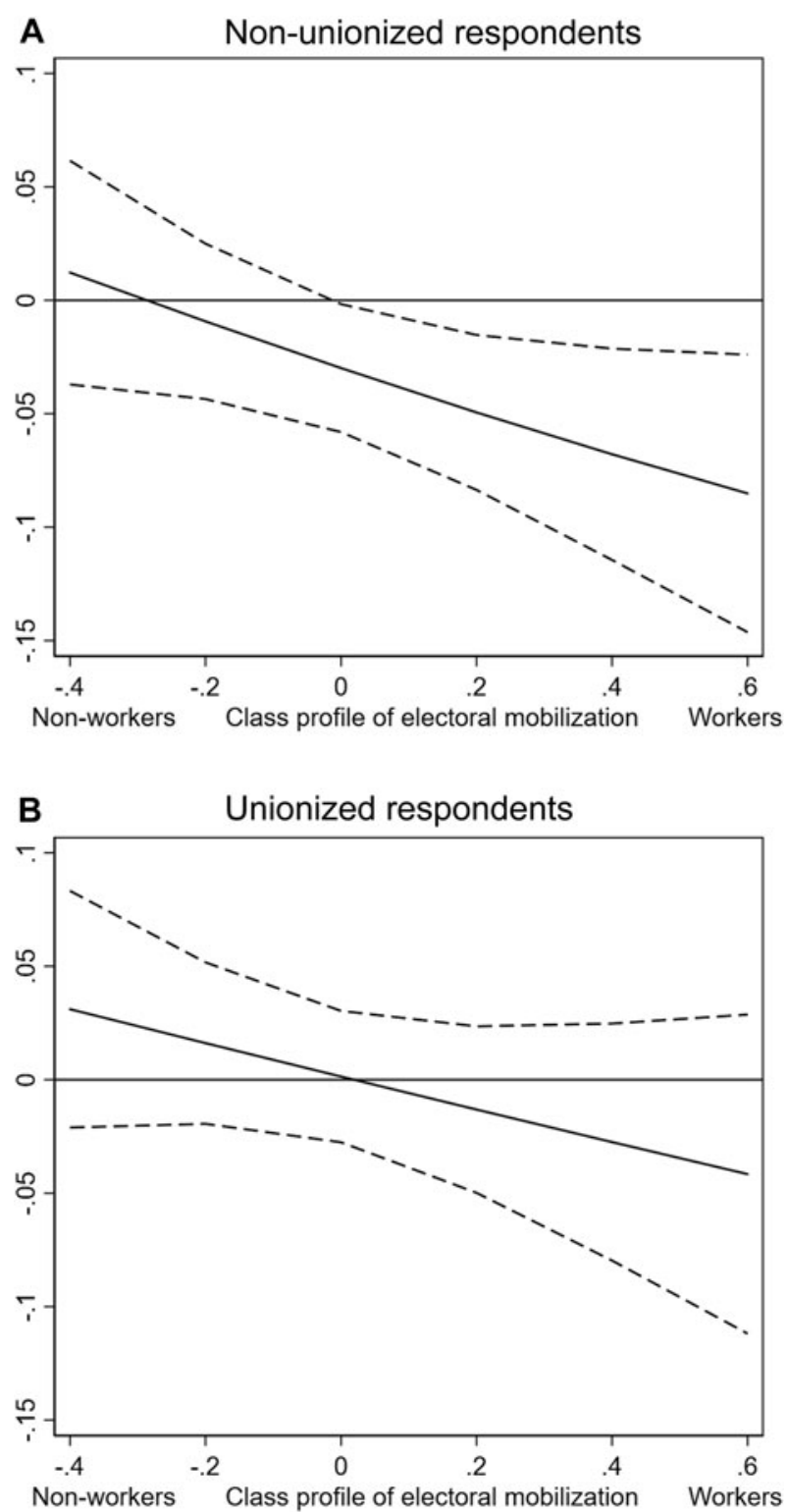

Based on Model 4 in online appendix 6. 


\begin{tabular}{|c|c|c|c|c|c|c|}
\hline & \multicolumn{6}{|c|}{ Class Profile of Electoral Mobilization } \\
\hline & -0.4 & -0.2 & 0 & 0.20 & 0.40 & 0.60 \\
\hline Workers & $\begin{array}{l}-0.070^{\star} \\
(0.014)\end{array}$ & $\begin{array}{l}-0.055^{\star \star} \\
(0.005)\end{array}$ & $\begin{array}{c}-0.040^{\star \star} \\
(0.009)\end{array}$ & $\begin{array}{l}-0.026 \\
(0.168)\end{array}$ & $\begin{array}{l}-0.013 \\
(0.614)\end{array}$ & $\begin{array}{l}-0.001 \\
(0.971)\end{array}$ \\
\hline $\begin{array}{l}\text { Socio-cultural } \\
\text { professionals }\end{array}$ & $\begin{array}{l}-0.079^{*} \\
(0.027)\end{array}$ & $\begin{array}{c}-0.069^{\star \star} \\
(0.006)\end{array}$ & $\begin{array}{c}-0.059^{\star \star} \\
(0.004)\end{array}$ & $\begin{array}{l}-0.049^{\star} \\
(0.048)\end{array}$ & $\begin{array}{l}-0.038 \\
(0.267)\end{array}$ & $\begin{array}{l}-0.028 \\
(0.543)\end{array}$ \\
\hline Other non-workers & $\begin{array}{c}-0.099^{\star \star *} \\
(0.000)\end{array}$ & $\begin{array}{c}-0.088^{\star \star \star} \\
(0.000)\end{array}$ & $\begin{array}{c}-0.077^{\star \star \star} \\
(0.000)\end{array}$ & $\begin{array}{c}-0.066^{\star \star} \\
(0.001)\end{array}$ & $\begin{array}{c}-0.055^{+} \\
(0.056)\end{array}$ & $\begin{array}{l}-0.043 \\
(0.273)\end{array}$ \\
\hline
\end{tabular}

and Sprague (1986), but this is not the case for middleclass de-unionization. ${ }^{14}$

\section{Where Have the Leavers Gone?}

We now turn to the question of where voters who abandoned the mainstream Left have gone or, more precisely, where they went when they abandoned the mainstream Left. As this analysis is restricted to "leavers," i.e., to survey respondents who say that they voted for the mainstream Left in the previous election and did not vote for the mainstream Left in the current election, the total number of observations is much smaller than in our analysis of the choice whether to abandon or stay with the mainstream Left.

We consider each of the following options available to voters who abandon the mainstream Left: 1) non-voting, 2) vote for a Center-Right party, 3) vote for a Green party, 4) vote for a radical Left party, or 5) vote for a radical Right party. Pooling all forty elections at our disposal, the distribution of choices by the 3,889 respondents who abandoned the mainstream Left is as follows: $45 \%$ voted for a Center-Right party, 16\% voted for the radical Left, $16 \%$ abstained from voting, $15 \%$ voted for the Greens, and $8 \%$ voted for the radical Right. The small number of leavers who turned to the radical Right comes as something of a surprise, but other studies (e.g., Evans and Mellon 2016) show that radical Right parties primarily draw voters from Center-Right parties and that mainstream-Left leavers who end up voting for the radical Right commonly transition through the Center-Right. (Of course, it may also be the case that right-wing populist parties have become more direct competitors of mainstream Left parties in elections since 2015).

As in the analysis of abandonment of the mainstream Left, we are interested in how class and union membership and the interaction between them shape the electoral behavior of individuals. Przeworski and Sprague's core argument is that supra-class strategies appeal to voters as individual citizens and thus turn workers into issueoriented voters without strong partisan attachments (e.g., Przeworski and Sprague 1986, 51). The implication would seem to be that workers who abandon the mainstream Left might go anywhere and should not be expected to behave differently from non-workers. At the same time, however, Przeworski and Sprague (74-79) suggest that the presence of rival parties that appeal to workers on the basis of class or some other "particularistic" identity renders the mainstream Left more vulnerable when it adopts supraclass strategies.

Going beyond Paper Stones, there can be little doubt that working-class households have fared badly by comparison to middle-class households in terms of income growth and economic insecurity since the 1990s. Globalization in general and immigration in particular threaten the economic status of workers to a far greater extent than they threaten the economic status of middle-class professionals. At the same time, the policy platforms on which mainstream Left parties have campaigned in elections (and implemented in government) have typically prioritized structural reforms designed to promote labor-market flexibility and fiscal consolidation at the expense of redistributive social spending (see, e.g., Rathgeb 2018, Horn 2018, and Bremer 2019). Against this background, it seems reasonable to suppose that workers who abandon the mainstream Left do so with other options in mind than their middle-class counterparts. More specifically, we hypothesize that, relative to middle-class leavers, workers who abandon the mainstream Left are more likely to abstain from voting and more likely to vote for "antiestablishment parties" of the radical Left or the radical Right. $^{15}$

We expect union membership to condition the effects of class. Many studies show that union members are more likely to vote and that the association between union membership and electoral participation is strongest for 
Figure 6

Average marginal effects of social class on the choice of options, with $95 \%$ confidence intervals
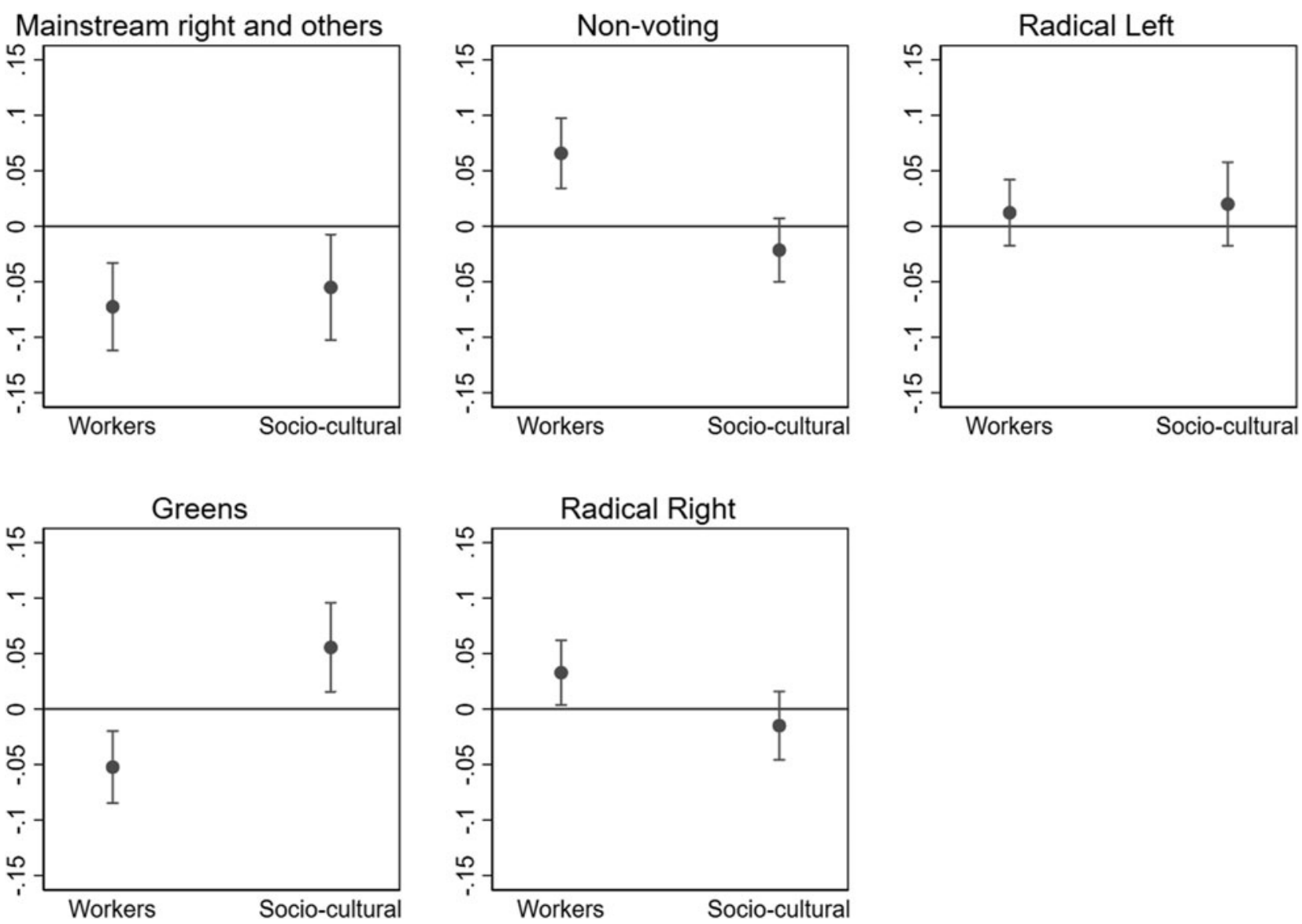

Based on Models 1-5 in online appendix 9. The effects shown are relative to the reference category of non-workers.

citizens with low socio-economic status (e.g., Kerrissey and Schofer 2013; Rosenfeld 2014). Other studies have shown that union membership is associated with support for redistribution (Mosimann and Pontusson 2017) and with support for immigration (Donnelly 2016). Drawing on these studies, we propose three additional hypotheses:

- Union membership reduces the propensity of workers who abandon the mainstream Left to abstain from voting.

- Union membership reduces the propensity of workers who abandon the mainstream Left to vote for the radical Right.

- Union membership increases the propensity of workers and non-workers to abandon the mainstream Left in favor of other Left parties.

For each of the five options identified here, we again estimate hierarchical logistic regression models, with random intercepts for each country and country-election. The dependent variable in each of the models is dichotomous: choosing the option or not. The models include the individual-level control variables identified earlier. As the class profile of electoral mobilization by Left parties is no longer relevant, we do not include any macro variables in this analysis (and hence we have no reason to drop cases with small numbers of new voters for Left parties). In estimating the models designed to predict voting for Greens, the radical Left, and the radical Right, we drop elections in which such parties were not meaningful options. ${ }^{16}$

Sticking with three classes (workers, socio-cultural professionals, and other non-workers) throughout the analysis, we begin by estimating models that do not interact class and union membership and then estimate models with interaction terms added. Reported in online appendix 9, the first set of models are less vulnerable to the small-N problem and, in any case, provide the most appropriate tests of our baseline hypotheses concerning differences between workers and non-workers who abandon the mainstream Left. Figure 6 summarizes graphically the results for social class. Relative to "other non-workers," workers who abandon the mainstream Left are more likely to abstain and to vote for the radical Right while they are less likely to vote for Greens and Center-Right parties. 
Table 5

Average marginal effects of union membership on the choice of options

\begin{tabular}{lc}
\hline Center-Right & $-.039^{+}(0.053)$ \\
Non-voting & $-.041^{\star \star}(0.003)$ \\
Radical Left & $.088^{\star *}(0.000)$ \\
Greens & $.021(0.172)$ \\
Radical Right & $-.011(0.430)$ \\
\hline
\end{tabular}

Based on Models $1-5$ in online appendix 9.

P-values in parentheses: ${ }^{+} p<0.10,{ }^{\star} p<0.05,{ }^{\star *} p<0.01,{ }^{\star \star \star} p<0.001$.

Table 6

Marginal effects of union membership on the choice of options conditional on social class

\begin{tabular}{lcccccc}
\hline & Workers (1) & $\begin{array}{c}\text { Socio-culturals } \\
\mathbf{( 2 )}\end{array}$ & $\begin{array}{c}\text { Other non-workers } \\
\mathbf{( 3 )}\end{array}$ & Diff 1-2 & Diff 1-3 & Diff 2-3 \\
\hline Center-Right & 0.018 & $-0.099^{\star}$ & $-0.059^{\star}$ & $0.117^{\star}$ & $0.078^{+}$ & -0.039 \\
& $(0.540)$ & $(0.010)$ & $(0.048)$ & $(0.013)$ & $(0.051)$ & $(0.404)$ \\
Non-voting & $-0.070^{\star *}$ & -0.003 & $-0.033^{+}$ & $-0.067^{\star}$ & -0.037 & 0.030 \\
& $(0.003)$ & $(0.905)$ & $(0.073)$ & $(0.032)$ & $(0.158)$ & $(0.288)$ \\
Radical Left & $0.074^{\star \star}$ & $0.125^{\star *}$ & $0.084^{\star *}$ & -0.051 & -0.010 & 0.041 \\
& $(0.006)$ & $(0.001)$ & $(0.002)$ & $(0.201)$ & $(0.755)$ & $(0.292)$ \\
Greens & -0.007 & $0.058^{+}$ & 0.021 & $-0.065^{+}$ & -0.028 & 0.037 \\
& $(0.712)$ & $(0.080)$ & $(0.377)$ & $(0.086)$ & $(0.347)$ & $(0.346)$ \\
Radical Right & -0.011 & $-0.053^{\star}$ & 0.009 & 0.042 & -0.020 & $-0.062^{+}$ \\
& $(0.596)$ & $(0.044)$ & $(0.646)$ & $(0.200)$ & $(0.454)$ & $(0.056)$ \\
\hline
\end{tabular}

Based on Models 6-10 in online appendix 9.

P-values in parentheses: ${ }^{+} p<0.10,{ }^{*} p<0.05,{ }^{\star \star} p<0.01$. T-test of equality hypothesis for differences.

Against the same benchmark, socio-cultural professionals are less likely to vote for Center-Right parties and more likely to vote for Green parties.

As shown in table 5, the direct effects of union membership are straightforward and, with one exception, consistent with our expectations. Controlling for social class, union members who abandon the mainstream Left are less likely to stop voting and less likely to vote for the Center-Right. Simply put, union members who abandon mainstream Left parties are more likely to remain on the Left, broadly conceived, than leavers who are not union members. Note, however, that these results do not bear our expectation concerning the radical Right: union members who abandon the mainstream Left are as likely to vote for the radical Right as respondents who are not union members.

Turning to the results of estimating interaction models, table 6 presents the marginal effects of union membership on choosing one of the five options conditional on respondents' social class. Among workers who abandon the mainstream Left, union membership is associated with continued voting and with voting for radical Left parties. Again, contrary to our expectations, unionized workers are not less likely to abandon the mainstream Left for the radical Right than non-union workers. Among socialcultural professionals, union membership moves Leftparty leavers away from the radical Right as well as the Center-Right, towards Greens and, most strongly, towards radical Left parties. Finally, among other non-workers who abandon the mainstream Left, union membership is also associated with a higher probability of voting for the radical Left and a lower probability of voting for the Center-Right.

\section{Conclusion}

Our analyses of CSES data for 2001-2015 show that class remains an important feature of electoral behavior in liberal democracies and, more specifically, that the tradeoff between working-class and middle-class support posited by Przeworski and Sprague (1986) continues to haunt Left parties. As suggested by the authors of Paper Stones, unionization of workers mitigates the electoral dilemma of the mainstream Left, but our results indicate that unionization of white-collar professionals and other middle-class strata does not have this effect. Middle-class voters who are unionized are more likely to vote for mainstream Left parties, as well as other Left parties, than middle-class voters who are not unionized, but they, too, 
Table 7

Correlates of the class profile of new voters (OLS regressions)

\begin{tabular}{|c|c|c|c|c|}
\hline & \multicolumn{2}{|c|}{ With GR 2012 and AT 2013} & \multicolumn{2}{|c|}{ Without GR 2012 and AT 2013} \\
\hline & (1) & (2) & (1) & (2) \\
\hline Right-Left position & $\begin{array}{l}.007^{*} \\
(.030)\end{array}$ & $\begin{array}{l}.006^{+} \\
(.070)\end{array}$ & $\begin{array}{l}.003 \\
(267)\end{array}$ & $\begin{array}{c}.001 \\
(.717)\end{array}$ \\
\hline & $\begin{array}{l}.030 \\
(.074)\end{array}$ & $\begin{array}{l}.032^{+} \\
(.059)\end{array}$ & $\begin{array}{l}.028^{+} \\
(.062)\end{array}$ & $\begin{array}{l}.032^{\star} \\
(.030)\end{array}$ \\
\hline No radical competitor & & $\begin{array}{l}.153 \\
(.335)\end{array}$ & & $\begin{array}{l}.271^{+} \\
(.057)\end{array}$ \\
\hline Constant & $\begin{array}{l}1.178 \\
(.000)\end{array}$ & $\begin{array}{l}1.132 \\
(.000)\end{array}$ & $\begin{array}{l}1.090 \\
(.000)\end{array}$ & $\begin{array}{l}.994 \\
(.000)\end{array}$ \\
\hline $\begin{array}{l}\mathrm{N} \\
\text { Adjusted R-square }\end{array}$ & $\begin{array}{l}38 \\
.127\end{array}$ & $\begin{array}{l}38 \\
.126\end{array}$ & $\begin{array}{l}36 \\
.067\end{array}$ & $\begin{array}{l}36 \\
.142\end{array}$ \\
\hline
\end{tabular}

Notes: P-values in parentheses: ${ }^{+} p<0.10,{ }^{*} p<0.05$.

Data on party platforms are from the Comparative Manifesto Project; Volkens et al. 2019a. The dependent variable is the class profile of new voters, as reported in yable 3. The Left-Right position is the standard measure of the Comparative Manifesto Project ("rile"), "prolabor statements" refers to variable "per 701," which the CMP codebook defines as "favourable references to all labour groups, the working class and unemployed workers in general" and "support for trade unions and calls for the good treatment of all employees" Volkens et al. 2019b, 20. All Australian elections, the New Zealand election of 2008, and the UK election of 2005 are coded as cases of "no radical competition." Norway 2013 and Finland 2015 are missing from this analysis for lack of CMP data.

become more likely to abandon Left parties when these parties target working-class voters in their mobilizational efforts. While unionization keeps middle-class voters on the Left, it may actually reinforce the trade-off between working-class and middle-class support for mainstream Left parties.

In short, union decline represents an electoral problem for Left parties and this problem assumes particular importance to the extent that union decline is concentrated among production and service workers. Good data on unionization rates by occupation are hard to come by, but for countries with separate bluecollar and white-collar unions, notably Sweden, we know that it is primarily blue-collar unions that have declined over the last twenty to thirty years (see Mosimann and Pontusson 2018). More broadly, available data indicate that unionization has held up much better in the public sector than in the private sector (Pontusson 2013) and that de-unionization has been most pronounced in the lower half of the earnings distribution (Becher and Pontusson 2011, Mosimann and Pontusson 2017).

In closing, it deserves to be noted that the preceding analysis does not speak to the question of whether or not some political projects-or, in other words, policy packages - that mainstream Left parties might pursue entail a sharper trade-off between working-class and middle-class support than others. It is tempting to suppose that "welfare-state universalism" allowed social democratic parties to mobilize middle-class voters as well as working-class voters in the postwar era and that recent electoral difficulties of the mainstream Left might be attributed to the exhaustion of this project. As Paper Stones reminds us, however, the postwar expansion of the welfare state was not accompanied by a steady expansion of electoral support for mainstream Left parties.

Our analysis emphasizes working-class organization (or lack thereof) as a condition enabling (constraining) Left parties to negotiate the dilemma of electoral socialism. Following Przeworski and Sprague, we have simply assumed that the class composition of new voters tells us something meaningful about strategic choices that parties make. But what is it that Left parties do (or might do) to mobilize working-class voters? As a first, very crude, attempt to address this question, table 7 presents the results of regressing our measure of the class profile of electoral mobilization on two features of party platforms captured by the Comparative Manifesto Project (CMP): the overall Right-Left position of manifestos and the percentage of positive mentions of labor-tradeunions, workers, and the working-class-in party manifestos. Needless to say, we do not suppose that ordinary citizens read party manifestos. The premise of this exercise is simply that manifestos tell us something meaningful about what parties say in their election campaigns.

The first set of results suggest that Left parties with more leftist platforms tend to mobilize more middle-class voters than working-class voters, but the association between these variables disappears once we drop Greece 2012 and Austria 2013. More intuitively, pro-labor statements in party manifestos are positively associated with relative mobilization of workers. This association 
holds up when we drop the two cases with very small numbers of new mainstream Left voters and becomes statistically more significant when we include a dummy that takes the value of 1 for elections in which radical Left and radical Right parties did not win a single parliamentary seat. As expected, the absence of radical competitors is also associated with more workers among new voters for the mainstream Left. ${ }^{17}$

In light of the small number of observations, the results presented in table 7 are, at best, suggestive. In our view, the main take-away is that being more "leftist" is not a universal formula for mobilizing working-class voters. This finding dovetails with our previous finding that unionized middle-class voters, especially socio-cultural professionals, often switch to radical Left parties when mainstream Left parties mobilize workers.

The results presented in table 7 also suggest that mainstream Left parties are more able to mobilize new working-class support when they do not face radical Left and radical Right competitors. This raises another question that we want to pursue in future work. In the analysis of electoral trade-offs presented above, we control for the vote shares of Green, radical Left, and radical Right parties in the previous election, but we do not interact these macro variables with respondents' class positions (and the effects of the control variables are rarely significant). In light of our analysis of where Leftparty leavers have gone, it seems plausible to suppose that the presence of radical options, especially radical Right options, increases the propensity of working-class voters to abandon the mainstream Left more than it increases the propensity of middle-class voters to abandon the mainstream Left.

Our results are based on generalizing across countries and over time. To address the question of whether or not electoral trade-offs have become more severe for mainstream Left parties, it would be worthwhile to replicate the macro-level analysis in Paper Stones with more recent data, but also to analyze surveys for individual countries going back to the 1960s. Less obviously perhaps, the preceding analyses assume that "union membership" has similar implications across countries and individuals. We have not taken into account that some unions are more closely affiliated with mainstream Left parties than others (see Arndt and Rennwald 2016) and that some are more solidaristic than others (Mosimann and Pontusson 2017). There are significant data constraints, but also exciting research opportunities in this domain.

While further nuance surely needs to be added, the core message of this paper boils down to the following proposition: for self-interested reasons, mainstream Left parties should worry about the decline of working-class organization and should strive to reverse this process. As many scholarly studies have shown, de-unionization is not an inevitable result of structural changes in advanced capitalist economies. ${ }^{18}$ To mention only a few examples, political decisions pertaining to the regulation of temporary employment contracts, outsourcing of public services, and the administration of unemployment insurance have important consequences for working-class organization. And working-class organization in turn has important electoral consequences.

\section{Notes}

1 For further information about CSES data, refer to http://www.cses.org/. The countries included in our individual-level analyses are Australia, Austria, Denmark, Finland, France, Germany, Greece, Iceland, Ireland, the Netherlands, New Zealand, Norway, Spain, Sweden, Switzerland, and the UK. (The elections analysed for each country are listed in the first column of table 3.) We also present some macro-level evidence for Belgium, Italy, and Portugal. We exclude the United States, Canada, Japan, and Eastern Europe from our macro-level analysis as well as individuallevel analyses because of the difficulty of identifying mainstream Left parties that satisfy of the criterion of having historically prioritized the mobilization of working-class voters. Refer to online appendix 1 for our coding of parties in the CSES dataset.

2 Note that post-1980 figures for Belgium represent the combined vote share of the Flemish and Francophone socialist parties, that the figures for France refer to the vote share of the Socialist Party in the first round of parliamentary elections, and that the 2019 vote share for the Greek socialists is the vote share for the socialist-dominated electoral alliance called the Movement for Change (KINAL). The measure employed here arguably understates the electoral strength of the French Socialist Party relative to other mainstream Left parties in the 1980s, 1990s, and 2000s. It is important to keep in mind that the French Socialists won three out of seven presidential elections between 1981 and 2017.

3 The figures for Iceland refer to the Social Democratic Alliance, formed in 2000 by the Social Democratic Party and several smaller leftist parties, while the figures for Italy refer to the Democratic Party, created in 2006. The Social Democratic Alliance performed better in the elections of 2003, 2007, and 2009 than the Social Democratic Party had ever done. The formation of the Italian Democratic Party was a complicated process involving the incorporation of former Radicals and Christian Democrats as well as the departure of the left-wing faction of the former Democratic Left Party, rendering cross-time comparisons particularly fraught, but note that the vote share of the Italian Communist Party (historical predecessor of the Democratic Left Party) peaked at $34.4 \%$ in 1976. 
4 The label "Center-Right parties" is here used as shorthand for "Center-Right and other parties." This category includes all parties that are not coded as mainstream Left, radical Left, Greens or radical Right (refer to online appendix 1).

5 Przeworski and Sprague's view of unions as enablers of the pursuit of supraclass electoral strategies by socialist parties stands in marked contrast to the view advanced by Kitschelt (1994). Influenced by the advances made by Southern European socialist parties in the 1980s, Kitschelt argues that strong unions represent a constraint on the ability of mainstream Left parties to reposition themselves in response to new political issues and cleavages.

6 Mainstream Left parties also held the office of Prime Minister in Austria and Norway in 2008-2011 and the association between union decline and vote-share losses for mainstream Left parties fails to clear the $90 \%$ significance threshold if these cases are also coded as "incumbency during crisis." Note that the Austrian rate of unemployment actually fell while the Norwegian rate increased very little during the crisis (from $2.5 \%$ in 2007 to $3.4 \%$ in 2011). These countries were clearly less affected by the crisis than the UK, let alone Iceland, Portugal, and Spain. Note also that the results for Model 4 in table 2 are robust to dropping the French case.

7 For European countries, the estimates the workingclass share of the electorate presented in online appendix 2 are very similar to estimates derived from the European Social Survey (see Rennwald 2015, 71). By our definition, the share of workers in the total electorate has declined since the 1970s, but not nearly as much as the share of production workers. Averaging across the five countries for which Rennwald (2015) provides data, the share of production workers in the total electorate fell from $33 \%$ to $19 \%$ while the share of service workers rose from $12 \%$ to $20 \%$ from the first half of the 1970s to the second half of the 2000s.

8 Nineteen of our forty CSES surveys include "not eligible to vote" as a possible answer to the question about voting in the previous election. In these cases, we include first-time voters in the calculation of our measure of the class profile of new voters for the mainstream Left. In the other cases, the category of new voters is restricted to the respondents who switched to the party in the election that just occurred. Respondents are coded as not having voted for the mainstream Left in the previous election if they declare that they voted for another party or that they did not vote. Respondents who did not answer the party choice or participation questions have been dropped. The accuracy of respondents' recall of how they voted, especially their recall of how they voted in the previous election (often four or five years past), is an obvious concern that bears on dependent variables and samples in the following analyses as well as our operationalization of the class profile of electoral mobilization by mainstream Left parties. Correlations between our survey-based estimates of the vote shares of Left parties and official elections as reported by Armingeon et al. 2018 suggest that this concern is not as serious as we expected when we started this project. For vote shares in the current election, the correlation is $.963(\mathrm{p}<.001)$; for vote share in the previous election, the correlation is .837 $(\mathrm{p}<.001)$; and for vote-share changes from the previous election, the correlation is .774 ( $\mathrm{p}<.001)$.

9 Refer to online appendix 4 for the formal notation of our main model, interacting respondents' social class with the class profile of electoral mobilization by mainstream Left parties. We obtain very similar results when we estimate models with country dummies and random effects at the country-election level (available on request).

10 As the only Spanish election included in the CSES database predates the crisis, and the British election of 2010 is not included in the CSES database, this dummy controls for the extraordinary circumstances of the Greek election of 2012 and the Icelandic election of 2013.

11 Full regression results are presented in online appendices 5 and 6 . The class profile variable has been centered at its mean value. The range varies depending on the size of the sample (thirty-eight or forty elections). The maximum value in figures $1 \mathrm{a}-1 \mathrm{~b}$ corresponds to 2.21 (Greece 2012 election) and the maximum value in figure $2 \mathrm{a}-2 \mathrm{~b}$ corresponds to 1.76 (Finland 2011). The minimum value in both figures corresponds to 0.79 (Switzerland 2011).

12 Dropping any one of the elections for which we have thirty or thirty-one new voters for mainstream Left parties (Finland 2007, 2011, 2015 and Iceland 2015), in addition to Greece 2012 and Austria 2013, yields results that are very similar to figures $2 \mathrm{a}-2 \mathrm{~b}$ (available upon request).

13 Refer to online appendices 7 and 8 for full regression results and measures of statistical significance.

14 Note that the results presented here are based on models that include age as a control variable. While older voters are less likely to abandon the mainstream Left, union members are not, on average, older than non-members.

15 On the appeal of right-wing populist parties for working-class voters, see Oesch 2008, Arzheimer 2013 and Afonso and Rennwald 2018.

16 In models of voting for the radical Left, we drop the New Zealand election of 2014 as well as all Australian and British elections; in models of voting for Greens, we drop all Icelandic and British elections; and in models of voting for the radical Right we drop the 
Swedish election of 2002, the British election of 2005, Australian elections of 2007 and 2013, as well as all Icelandic, Irish, and Spanish elections. Literally no mainstream Left leavers voted for these options in the cases that have been dropped.

17 As shown in online appendix 10, the statistical significance of the effects of pro-labor statements improves when we estimate these models with standard errors clustered by country. Online appendix 11 presents the results of replicating the analysis with measures of programmatic party positions from the Chapel Hill Expert Survey: with a much reduced number of observations, we still find a significant positive association between pro-labor statements (as reported by the CMP) and workers' representation among new voters.

18 See Tucker 2018 for a useful review of relevant literature.

\section{Supplementary Materials}

Appendix 1. Classification of Parties in CSES Dataset Appendix 2. The Class Composition of the Electorate, Averages for Available Election Surveys, 2001-2015

Appendix 3, Unionization by Social Class, Averages for Available Election Surveys

Appendix 4. Formal Notation

Appendix 5. Class, Union Membership, and the Decision to Leave the Mainstream Left, 2-Class Models with Forty Elections, for Figure 1

Appendix 6. Class, Union Membership, and the Decision to Leave the Mainstream Left, 2-Class Models with Thirty-Eight Elections, for Figures 2, 4, and 5

Appendix 7. Class, Union Membership, and the Decision to Leave the Mainstream Left, 3-Class Models with Thirty-Eight Elections, for Figure 3 and Table 4

Appendix 8. Statistical Significance of Class Differences in Figure 3

Appendix 9. Class, Union Membership, and New Voting Choices of Mainstream Left Leavers, 3-Class Models with Max. Forty Elections, for Figure 6 and Tables 5 and 6 Appendix 10. Replication of Table 7 with Standard Errors clustered by Country (without Greece 2012 and Austria 2013)

Appendix 11. Replication of Table 7 with Measures of Party Positions from the Chapel Hill Expert Survey (without Greece 2012 and Austria 20 13)

To view supplementary material for this article, please visit https://doi.org/10.1017/S1537592720000067

\section{References}

Afonso, Alexandre and Line Rennwald. 2018. "Social Class and the Changing Welfare State Agenda of Radical Right Parties in Europe." In Welfare Democracies and Party Politics: Explaining Electoral Dynamics in Times of Changing Welfare Capitalism, ed. Philipp
Manow, Hanna Schwander and Bruno Palier, 171194. Oxford: Oxford University Press.

Armingeon, Klaus, Christian Isler, Laura Knöpfel, David Weisstanner, and Sarah Engler. 2018. Comparative Political Data Set 1960-2016. Bern: Institute of Political Science, University of Berne.

Arndt, Christoph and Line Rennwald. 2016. "Union Members at the Polls in Diverse Trade Union Landscapes." European Journal of Political Research 55(4): 702-22.

Arzheimer, Kai. 2013. "Working-Class Parties 2.0? Competition between Centre-Left and Extreme Right Parties." In Class Politics and the Radical Right, ed. Jens Rydgren, 75-90. London: Routledge.

Becher, Michael and Jonas Pontusson. 2011. "Whose Interests Do Unions Represent? Unionization by Income in Western Europe." Research in the Sociology of Work 22(2): 181-211.

Bremer, Björn. 2019. Austerity from the Left: Explaining the Fiscal Policies of Social Democratic Parties in Response to the Great Recession. PhD dissertation, European University Institute, Florence.

Donnelly, Michael J. 2016. "Competition and Solidarity: Union Members and Immigration in Europe." West European Politics 39(4): 688-709.

Evans, Geoffrey and Nan Dirk De Graaf. 2013. "Explaining Cleavage Strength: The Role of Party Positions." In Political Choice Matters. Explaining the Strength of Class and Religious Cleavages in CrossNational Perspective, ed. Geoffrey Evans and Nan Dirk De Graaf, 3-26. Oxford: Oxford University Press.

Evans, Geoffrey and Jon Mellon. 2016. "Working Class Votes and Conservative Losses: Solving the UKIP Puzzle." Parliamentary Affairs 69(2): 464-79.

Evans, Geoffrey and James Tilley. 2017. The New Politics of Class: The Political Exclusion of the British Working Class. Oxford: Oxford University Press.

Gallagher, Michael. N.d. "Election Indices." Department of Political Science, Trinity College Dublin. Retrieved August 2019 (https://www.tcd.ie/ Political_Science/people/michael_gallagher/ ElSystems/Docts/ElectionIndices.pdf).

Gingrich, Jane and Silja Häusermann. 2015. "The Decline of the Working-Class Vote, the Reconfiguration of the Welfare Support Coalition and Consequences for the Welfare State." Journal of European Social Policy 25(1): 50-75.

Häusermann, Silja and Hanspeter Kriesi. 2015. "What Do Voters Want? Dimensions and Configurations in Individual-Level Preferences and Party Choice." In The Politics of Advanced Capitalism, ed. Pablo Beramendi, Silja Häusermann, Herbert Kitschelt and Hanspeter Kriesi, 202-230. Cambridge: Cambridge University Press.

Horn, Alexander. 2018. "The Asymmetric Long-Term Consequences of Unpopular Reform.” Presented at the 
Annual International Conference of Europeanists, Chicago, March.

Kerrissey, Jasmine and Evan Schofer. 2013. "Union Membership and Political Participation in the United States." Social Forces 91(3): 895-928.

Kitschelt, Herbert. 1994. The Transformation of European Social Democracy. Cambridge Studies in Comparative Politics. Cambridge: Cambridge University Press.

Kitschelt, Herbert and Philipp Rehm. 2014. "Occupations as a Site of Political Preference Formation." Comparative Political Studies 47(12): 1670-706.

Kriesi, Hanspeter. 1998. "The Transformation of Cleavage Politics. The 1997 Stein Rokkan Lecture.” European Journal of Political Research 33(2): 165-85.

Mosimann, Nadja and Jonas Pontusson. 2017. "Solidaristic Unionism and Support for Redistribution in Contemporary Europe." World Politics 69(3): 448-92. - 2018. "Heterogeneity of the Trade-Union Membership Effect on Support for Redistribution in Western Europe.” Unequal Democracies Working Paper no. 12. University of Geneva. (https:// unequaldemocracies.unige.ch/files/5515/7848/9296/ wp12.pdf).

Oesch, Daniel. 2006. Redrawing the Class Map. Stratifcation and Institutions in Britain, Germany, Sweden and Switzerland. London: Palgrave Macmillan.

. 2008. "Explaining Workers' Support for RightWing Populist Parties in Western Europe: Evidence from Austria, Belgium, France, Norway and Switzerland." International Political Science Review 29(3): 349_ 73.

Pontusson, Jonas. 2013. "Unionization, Inequality and Redistribution." British Journal of Industrial Relations 51(4): 797-825.

Przeworski, Adam and John Sprague. 1986. Paper Stones: A History of Electoral Socialism. Chicago, London: University of Chicago Press.

Rathgeb, Philip. 2018. Strong Governments, Precarious Workers: Labour Market Policy-Making in the Era of Liberalisation. Ithaca, NY: Cornell University Press.
Rennwald, Line. 2015. Partis Socialistes et Classe Ouvrière. Ruptures et Continuités du Lien électoral en Suisse, en Autriche, en Allemagne, en Grande-Bretagne et en France (1970-2008). Neuchâtel: Editions Alphil-Presses universitaires suisses.

Rennwald, Line and Geoffrey Evans. 2014. "When Supply Creates Demand: Social Democratic Party Strategies and the Evolution of Class Voting." West European Politics 37(5): 1108-35.

Rosenfeld, Jake. 2014. What Unions No Longer Do. Cambridge, MA: Harvard University Press.

Sainsbury, Diane. 1990. "Party Strategies and the Electoral Trade-Off of Class-Based Parties.” European Journal of Political Research 18(1): 29-50.

Schmidt-Catran, Alexander W. and Malcolm Fairbrother. 2016. "The Random Effects in Multilevel Models: Getting Them Wrong and Getting Them Right." European Sociological Review 32(1): 23-38.

Thau, Mads. 2017. "How Political Parties use GroupBased Appeals: Evidence from Britain 1945-2015.” Political Studies 61(1): 63-82.

Tucker, Todd. 2018. Seven Strategies to Rebuild Worker Power for the 21st Century Global Economy: A Comparative and Historical Framework for Policy Action. New York: Roosevelt Institute.

Visser, Jelle. 2019. Database on Institutional Characteristics of Trade Unions, Wage Setting, State Intervention and Social Pacts in 55 Countries from 1960 to 2017. 1960 2014 (ICTWSS), Version 6.0. Amsterdam Institute for Advanced Labour Studies, University of Amsterdam (http://www.uva-aias.net/en/ictwss).

Volkens, Andrea, Werner Krause, Pola Lehmann, Theres Matthieß, Nicolas Merz, Sven Regel, and Bernhard Weßels. 2019a. The Manifesto Data Collection: Manifesto Project (MRG/CMP/MARPOR), Version 2019a. Berlin: Wissenschaftszentrum für Sozialforschung (https://manifesto-project.wzb.eu/).

- 2019b. The Manifesto Project Dataset Codebook: Manifesto Project (MRG/CMP/MARPOR), Version 2019a. Berlin: Wissenschaftszentrum für Sozialforschung (https://manifesto-project.wzb.eu/). 